\title{
Can having siblings increase stuttering as compared to being an only child?
}

\section{Yoshikazu Kikuchi ${ }^{1 *}$, Toshiro Umezaki ${ }^{2,3}$, Kazuo Adachi ${ }^{2,4}$, Motohiro Sawatsubashi ${ }^{5}$, Masahiko Taura ${ }^{6}$, Yumi Yamaguchi ${ }^{1}$, Keiko Fukui ${ }^{1}$, Nana Tsuchihashi ${ }^{1}$, Daisuke Murakami ${ }^{1}$ and Takashi Nakagawa ${ }^{1}$}

${ }^{1}$ Department of Otorhinolaryngology, Graduate School of Medical Sciences, Kyushu University, Fukuoka, Japan

${ }^{2}$ Voice and Swallowing Center, Fukuoka Sanno Hospital, Fukuoka, Japan

${ }^{3}$ International University of Health and Welfare, Fukuoka, Japan

${ }^{4}$ Adachi Otorhinolaryngology clinic, Fukuoka, Japan

${ }^{5}$ Department of Otorhinolaryngology, Fukuoka University Chikushi Hospital, Fukuoka, Japan

${ }^{6}$ Department of Otorhinolaryngology, Fukuoka University Hospital, Fukuoka, Japan

*Corresponding author: Yoshikazu Kikuchi, MD, PhD, Department of Otorhinolaryngology, Graduate School of Medical Sciences, Kyushu University, 3-1-1 Maidashi, Higashi-ku, Fukuoka 812-8582, Japan, Tel: +81-92-642-5668, Fax: +81-92$642-5685$

\begin{abstract}
Background: Stuttering is a speech fluency disorder. Although recent studies have shown that most of its etiology is genetic, some parents considered their own caregiving or siblings as the cause of stuttering. This study aimed to address the clinical question associated with whether having siblings increases the risk of stuttering.

Methods: We assessed the numbers and proportions of sibship size and birth order of 102 people who stutter (76 males and 26 females; average 11.8 years). In addition, we compared the occurrence of only children and siblings in our stuttering data with those in the $15^{\text {th }}$ Japanese National Fertility Survey database.

Results: There were $22(21.6 \%)$ only children and 80 $(78.4 \%)$ siblings in our stuttering data, and there were 229 $(19.8 \%)$ only children and $927(80.2 \%)$ siblings in the $15^{\text {th }}$ Japanese National Fertility Survey database. A chi-square analysis revealed that the observed frequencies in the siblings' categories were not significantly different from those of only children.

Conclusions: The only child proportion of our stuttering population was similar to that of the 15th Japanese National Fertility Survey data. Our findings will assist parents and sibships to encourage self-confidence and prevent negative beliefs in the form of self-blame, guilt or shame associated with stuttering.
\end{abstract}

\section{Keywords}

Children who stutter, Siblings, Speech fluency disorder, Only child

\section{Introduction}

Stuttering is a speech fluency disorder characterized by involuntary repetitions or prolongation of words, syllables, or sounds, or interruptions in the flow of speech, known as blocks. It generally emerges at the age of 2-4 years, with incidence rates ranging from approximately 5-11.2\% [1-3]. The onset of stuttering is rapid (one day or a few days) in $40-53.2 \%$ of stutters [3-5]. For many years, parents have been considered to play a role in the development of stuttering. Johnson's diagnosogenic theory suggested that parenting may result in the emergence of stuttering by abnormal reactions to and false labeling of their children's typical disfluencies [6]. However, the theory was refuted by other researchers $[7,8]$. Recent twin studies have produced estimates of high heritability, often exceeding 0.80 [9]. Studies on the genetics of stutter revealed that GNPTAB, GNPTG, NAGPA, and AP4E1 are related with the lysosomal targeting pathway [10-13]. The cortical expression levels of the lysosomal

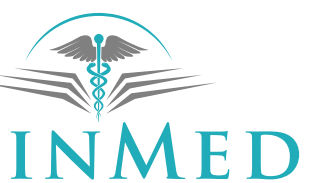

INTERNATIONAL LIBRARY

Citation: Kikuchi Y, Umezaki T, Adachi K, Sawatsubashi M, Taura M, et al. (2020) Can having siblings increase stuttering as compared to being an only child?. Int Arch Commun Disord 3:017. doi. org/10.23937/2643-4148/1710017

Accepted: November 19, 2020: Published: November 21, 2020

Copyright: (c) 2020 Kikuchi Y, et al. This is an open-access article distributed under the terms of the Creative Commons Attribution License, which permits unrestricted use, distribution, and reproduction in any medium, provided the original author and source are credited. 
genes have been observed to alter functional connectivity network organization of stuttering-related brain regions [14]. Additionally, there is some evidence of an association between temperament and stuttering [15].

Despite shifts in the understanding of the etiology of stuttering, parents often resort to self-blame, stating that they feel like they somehow caused their child's stuttering [16]. Not only do parents experience anxiety, but siblings also experience negative emotions surrounding siblings' stuttering [17]. A few years ago, we met a fluent young sister whose older sister stuttered. She was told by her mother, "The reason that older sister was stuttering was that you were born." She also told us about her self-blame: "I changed older sister to a person who stutters. I wish I was never born." Therefore, this study sought to determine whether stuttering occurred more among siblings than only children. There have been a few prior sibling studies. For example, a twin children study on stuttering revealed that stuttering occurs irrespective of birth order [18]. In a prospective, community cohort study, which studied cases with the onset of stuttering by the age of 3 and 4 years, the proportion of older siblings who were stutterers did not differ from those in nonstutterers [2,3]. The birth order of siblings had no bearing on cases of recovered and persistent stuttering [19]. Morgenstern observed no difference from the expected number of only children from among 355 stutterers [20]. Rotter and Morgestern agreed with the finding on the average nonstutterer, but this difference appeared neither in the Newcastle data nor the findings of Gladstien, Seider, and Kidd [21]. However, the famous stuttering textbook [20] published in 2006 suggested that the possible trigger linked to the onset of stuttering may be linked to having both younger and older siblings. The textbook stated: "The birth of a new brother or sister may trigger the child's insecurity with threat of being replaced. Or, an older sibling may turn belligerent toward the child because of the older child's own need to express aggression as a prelude to puberty. Just as these stressors wax and wane in strength during preschool years, so does the child's stuttering." [22].

The aim of study was to address the clinical question surrounding whether having siblings increases stuttering compared to being an only child. The birth rate, sibship size, and completed fertility (the average number of children born to a given generation of women throughout their fertile lives) in previous studies varies across time period and country. Although the textbook published in 2006 spoke to the possibility of siblings triggering stuttering, we sought to challenge this assumption by testing the frequency of stuttering among only children and siblings.

\section{Methods}

Participants consisted of 102 people who stutter (PWS) (76 males and 26 females; average age 11.8, ranging from 3 to 44), who visited Kyushu University Hospital from 2013 to 2015 for consultations with regard to their stuttering. There were no exclusion criteria. We assessed the numbers and proportions of sibship size and birth order of 102 PWS. In addition, we compared the frequency of only children and siblings in our stuttering data with those in the $15^{\text {th }}$ Japanese National Fertility Survey database [23]. This survey was conducted to determine the current situations of and background to marriage and/or fertility of married couples in 2015. The survey indicated that the completed fertility rate was 1.94. Of the 1,156 married couples, who were married on average 15 to 19 years, 229 couples had one child (19.8\%), 665 had two children (57.5\%), 221 had three children (19.1\%), and 41 couples had four or more children (3.5\%). A Pearson's chi-square test using statistical software JMP ${ }^{\circledR} 14$ (SAS Institute Inc., Cary, NC, USA) was carried out comparing the frequency of only children and siblings in our stuttering data and the $15^{\text {th }}$ Japanese National Fertility Survey database. This study was approved by the institutional review board of Kyushu University (29-117) and was performed in accordance with the Declaration of Helsinki.

\section{Results}

Table 1 shows the distribution of sibship size and birth order in our stuttering population. Most couples had two children, and no couples had more than four children in total.

Table 1: Distribution of sibship size and birth order for 102 people who stutter from Kyushu University Hospital.

\begin{tabular}{|c|c|c|c|c|c|}
\hline Sibship size & First & Second & Third & Fourth & Total \\
\hline 1 & 22 & - & - & - & 22 \\
\hline 2 & 43 & 25 & - & - & 68 \\
\hline 3 & 1 & 7 & 2 & - & 10 \\
\hline 4 & 0 & 0 & 2 & 0 & 2 \\
\hline
\end{tabular}

Table 2: Comparison of our stuttering data and the $15^{\text {th }}$ Japanese National Fertility Survey database.

\begin{tabular}{|c|c|c|c|}
\hline & Our stuttering data & $\begin{array}{l}\text { The 15 } \\
\text { Survey database }\end{array}$ & $\begin{array}{l}\text { P value for difference } \\
\text { (Confidence Intervals) }\end{array}$ \\
\hline $\begin{array}{c}\text { Only child } \\
\text { Boy }\end{array}$ & $22(21.6 \%)$ & $229(19.8 \%)$ & 0.67 \\
Girl & 17 & 103 & $(0.54$ to 1.47$)$ \\
\hline Siblings & 5 & 126 & \\
\hline Total & $80(78.4 \%)$ & $927(80.2 \%)$ & \\
\hline
\end{tabular}


Table 2 shows the occurrence of only children and siblings in our stuttering data and the $15^{\text {th }}$ Japanese $\mathrm{Na}$ tional Fertility Survey database. There were 22 couples with only one child (21.6\%). In addition, there were 80 (78.4\%) siblings in our stuttering data, and there were 229 (19.8\%) with an only child and 927 (80.2\%) siblings in the $15^{\text {th }}$ Japanese National Fertility Survey database. According to chi-square analysis, the observed frequency for the siblings categories did not differ significantly from that of only children $\left(\chi^{2}=0.182, d f=1, p=0.67\right)$.

\section{Discussion}

The proportion of only children among our stuttering population was similar to that of the $15^{\text {th }}$ Japanese National Fertility Survey data. The survey was carried out every 5 years. It consists of the most reliable database in our country with respect to sibship size. We found no difference with regards to stuttering between siblings and only children between our data and the survey. This confirmed that the proportion of children who developed stuttering did not rise with siblings. Beilby, et al. interviewed 12 fluent siblings of children who stuttered and had strongly negative emotions [17]. The young sister with a strong amount of self-blame presented in the introduction may be a rare case, but some parents believe the cause of stuttering in a new sibling may be linked to other children's stress. They believe that they may tell the fluent siblings that their birth was the cause of sibling's stuttering. Our findings will help parents and sibships to encourage self-esteem and prevent negative beliefs in the form of self-blame, guilt, or shame associated with stuttering.

Among our sibling data, there were more first born children who stuttered than second born among the categories of siblings who formed a total of two. We considered three reasons for which stuttering might most affect the first born child in such cases. First, most parents of first born had their anxiety linked to entering elementary school. For example, they stated: "We are worrying if our first born children go to elementary school next year, it may will affect their relationship with other kids.", "We are afraid that stuttering children of being teased or bullied in coming years at school. How will we ask teacher to prevent teasing and bulling?" Second, our data was derived from a retrospective study. However, the prospective and cohort study in Reilly, et al. showed no difference with regard to the occurrence of older children between stuttering and non-stuttering groups [2,3]. In addition, Ooki used the largest databases of twins; no significant difference was revealed across birth orders [16]. Third, our data was derived at the time of the first consultation to our clinic.

This study has several limitations. First, our data consisted of a retrospective chart study. Reilly, et al.'s studies consisted of prospective, cohort studies and assessed whether individuals had older siblings, without assessing whether they had younger siblings $[2,3]$. Fur- thermore, we used the $15^{\text {th }}$ Japanese National Fertility Survey database in 2015 as control group [23]. Use of our own control group would have been preferable. However, the survey database consisted of over 1,000 families and reflected the most reliable sibship data in our country. Third, we did not have access to stuttering ratios in our stuttering group. Therefore, we were not able to examine the associations between stuttering severity, birth order and siblings.

\section{Acknowledgments}

We would like to thank Editage (www.editage.jp) for English language editing.

\section{Disclosure statement}

The authors have no conflicts of interest to disclose.

\section{Financial Disclosures}

This work was supported by JSPS KAKENHI Grant Number JP17K16922, JP20K02299, Japan Agency for Medical Research and Development (AMED) 19dk0310102j0001, and Health and Labor Sciences Research Grants (19GC1001).

\section{References}

1. Månsson H (2000) Childhood stuttering: Incidence and development. J Fluency Disord 25: 47-57.

2. Reilly $S$, Onslow M, Packman A, Cini E, Conway L, et al. (2013) Natural history of stuttering to 4 years of age: A prospective community-based study. Pediatrics 132: 460-467.

3. Reilly S, Onslow M, Packman A, Wake M, Bavin EL, et al. (2009) Predicting stuttering onset by the age of 3 years: A prospective, community cohort study. Pediatrics 123: 270277.

4. Yairi E, Ambrose N (2005) Early childhood stuttering. Austin: Pro-Ed, Inc.

5. Buck SM, Lees R, Cook F (2002) The influence of family history of stuttering on the onset of stuttering in young children. Folia Phoniatr Logop 54: 117-124.

6. Johnson W (1959) The onset of stuttering: Research findings and implications. Minneapolis: University of Minnesota Press.

7. Ambrose NG, Yairi E (2002) The Tudor Study: Data and ethics. American Journal of Speech-Language Pathology 11: 190-203.

8. Bloodstein O, Bernstein Ratner NA (2008) Handbook on stuttering. (6 $6^{\text {th }}$ edn), Thomson- Delmar, Loodstein.

9. Frigerio-Domingues C, Drayna D (2017) Genetic contributions to stuttering: The current evidence. Mol Genet Genomic Med 5: 95-102.

10. Kang C, Riazuddin S, Mundorff J, Krasnewich D, Friedman $P$, et al. (2010) Mutations in the lysosomal enzyme-targeting pathway and persistent stuttering. $\mathrm{N}$ Engl J Med 362: 677-685.

11. Kang C, Drayna D (2012) A role for inherited metabolic deficits in persistent developmental stuttering. Mol. Genet Metab 107: 276-280.

12. Raza MH, Mattera $R$, Morell $R$, Sainz $E$, Rahn $R$, et al. (2015) Association between rare variants in AP4E1, a com- 
ponent of intracellular trafficking, and persistent stuttering. Am J Hum Genet 97: 715-725.

13. Raza MH, Domingues CE, Webster R, Sainz E, Paris E, et al. (2016) Mucolipidosis types II and III and non-syndromic stuttering are associated with different variants in the same genes. Eur J Hum Genet 24: 529-534.

14. Benito-Aragón C, Gonzalez-Sarmiento R, Liddell T, Diez I, d'Oleire Uquillas F, et al. (2020) Neurofilament-lysosomal genetic intersections in the cortical network of stuttering. Prog Neurobiol 184: 101718.

15. Kefalianos E, Onslow M, Block S, Menzies R, Reilly S (2012) Early stuttering, temperament and anxiety: Two hypotheses. J Fluency Disord 37: 151-163.

16. Langevin M, Packman A, Onslow M (2010) Parent perceptions of the impact of stuttering on their preschoolers and themselves. J Commun Disord 43: 407-423.

17. Beilby JM, Byrnes ML, Young KN (2012) The experiences of living with a sibling who stutters: A preliminary study. J Fluency Disord 37: 135-148.
18. Ooki S (2005) Genetic and environmental influences on stuttering and tics in Japanese twin children. Twin Res Hum Genet 8: 69-75.

19. Seider RA, Gladstien KL, Kidd KK (1983) Recovery and persistence of stuttering among relatives of stutterers. J Speech Hear Disord 48: 402-409.

20. Morgenstern JJ (1956) Socio-economic factors in stuttering. J Speech Hear Disord 21: 25-33.

21. Gladstien KL, Seider RA, Kidd KK (1981) Analysis of the sibship patterns of stutterers. J Speech Hear Res 24: 460462.

22. Guitar B (2006) Stuttering: An integrated approach to its nature and treatment. ( $3^{\text {rd }}$ edn), p149. Philadelphia, PA: Lippincott Williams \& Wilkins.

23. National Institute of Population and Social Security Research. Marriage and Childbirth in Japan Today: The Fifteenth Japanese National Fertility Survey, 2015 (Results of Singles and Married Couples Survey). 